\title{
Peran Media Iklan Televisi Sebagai Media Kritik Sosial Kasus Korupsi (Studi Kasus Pada Iklan Djarum 76 Versi “Kontes Jin")
}

\author{
Ita Suryani \\ Dosen atau Staff Pengajar \\ Akademi Komunikasi Bina Sarana Informatika
}

\begin{abstract}
Corruption should be viewed as an extraordinary crime, are therefore also require tremendous efforts to eradicate it . Efforts to combat corruption which is composed of two major parts, namely (1) the prosecution, and (2) prevention -not will never work optimally if it is only done by government alone without involving the participation to people's media industry. Therefore, advertising media can be used as an important part that can act as a medium of social criticism on the issue of corruption in Indonesia .

Djarum 76 for example, ads Djarum 76 as we know it often featured social themes which then can be understood as a form of social criticism. By generating genie figure in each advertisement , Djarum 76 trying to tell its products as manufacturers concentrated on social issues. Image that emerges from these ads is Djarum 76 care social problems that exist, which is then displayed in the form of parody, but full of meaning and social criticism.

The method used in this study is case study method which is a research method that uses a variety of data sources that can be used to examine, comprehensively describe and explain the various aspects of individual, group, program, organization or event systematically.

The conchusion shows that overall this ad is a form of social criticism that talk about corruption. The elimination of corruption cases were warmly welcomed by everyone who is represented by the audience. However, there is an allusion encountered, which is waiting for the appearance of the genie to resolve corruption cases. Satire is focused on the relevant parties are in fact not able to investigate all cases of corruption. One case took a long time to be completed, while a genie completed all in the blink of an eye .
\end{abstract}

Keywords : Advertising, Corruption and Social Criticism. 


\section{Pendahuluan}

Akhir-akhir ini masalah korupsi sedang hangat-hangatnya dibicarakan publik, terutama dalam media massa baik lokal maupun nasional. Banyak para ahli mengemukakan pendapatnya tentang masalah korupsi ini. Pada dasarnya, ada yang pro adapula yang kontra. Akan tetapi walau bagaimanapun korupsi ini merugikan negara dan dapat meusak sendi-sendi kebersamaan bangsa.

Pada hakekatnya, korupsi adalah "benalu sosial" yang merusak struktur pemerintahan, dan menjadi penghambat utama terhadap jalannya pemerintahan dan pembangunan pada umumnya.

Dalam prakteknya, korupsi sangat sukar bahkan hampir tidak mungkin dapat diberantas, oleh karena sangat sulit memberikan pembuktian-pembuktian yang eksak. Disamping itu sangat sulit mendeteksinya dengan dasar-dasar hukum yang pasti. Namun akses perbuatan korupsi merupakan bahaya latent yang harus diwaspadai baik oleh pemerintah maupun oleh masyarakat itu sendiri.

Korupsi dapat menghambat pertumbuhan ekonomi, korupsi juga menghambat pengembangan sistem pemerintahan demokratis. Korupsi memupuk tradisi perbuatan yang menguntungkan diri sendiri atau kelompok, yang mengesampingkan kepentingan publik. Dengan begitu korupsi menutup rapat-rapat kesempatan rakyat lemah untuk menikmati pembangunan ekonomi, dan kualitas hidup yang lebih baik.

Peraturan perundang-undangan (legislation) merupakan wujud dari politik hukum institusi Negara dirancang dan disahkan sebagai undang-undang pemberantasan tindak pidana korupsi. Secara parsial, dapat disimpulkan pemerintah dan bangsa Indonesia serius melawan dan memberantas tindak pidana korupsi di negeri ini. Tebang pilih. Begitu kira-kira pendapat beberapa praktisi dan pengamat hukum terhadap gerak pemerintah dalam menangani kasus korupsi akhir-akhir ini.

Gaung pemberantasan korupsi seakan menjadi senjata ampuh untuk dibubuhkan dalam teks pidato para pejabat Negara, bicara seolah ia bersih, anti korupsi. Masyarakat melalui LSM dan Ormas pun tidak mau kalah, mengambil manfaat dari kampanye anti korupsi di Indonesia. Pembahasan mengenai strategi pemberantasan korupsi dilakukan dibanyak ruang seminar, booming anti korupsi, begitulah tepatnya. Meanstream perlawanan terhadap korupsi juga dijewantahkan melalui pembentukan lembaga Adhoc, Komisi Pemberantasan Korupsi (KPK).

Ulasan iklan televisi oleh Djarum 76 dengan versi "Kontes Jin" yang memang peduli akan keadaan di negara Indonesia dengan tingkat korupsinya sudah cukup mengkhawatirkan untuk disadarkan bahwa korupsi tidak akan membawa kebaikan justru akan merugikan dan menghancurkan bangsa dan negara. Masyarakat perlu disadarkan akan pentingnya pemberantasan korupsi sampai dengan ke akar-akarnya. Karena masyarakat belum sadar akan bahaya yang mengancam tersebut dan seolah telah menjadi budaya.

Berdasarkan alasan tersebut, penulis tertarik membahas mengenai "Peran Media Iklan Televisi Sebagai Media Kritik Sosial Kasus Korupsi (Studi Kasus Pada Iklan Djarum 76 Versi Kontes Jin)" akan mendapat interpretasi makna yang penuh dengan tanda-anda visual baik secara verbal dan nonverbal.

Tujuan yang ingin dicapai penulis dalam mengangkat tema ini adalah untuk mengetahui bagaimana peran media iklan 
sebagai salah satu media kritis sosial terkait masalah korupsi.

\section{STUDI IITERATURE}

\section{Iklan}

Iklan merupakan alat komunikasi yang efektif bagi para perusahaan produk atau jasa untuk mengkomunikasikan pesan kepada masyarakat Iuas tentang informasi produk a atau jasa, mengingatkannya, membujuk para masyarakat untuk menggunakan produk atau jasa tersebut.

Menurut Griffin dan Ebert (2007:368) iklan adalah alat komunikasi tidak langsung, yang dibayar, digunakan oleh sponsor tertentu untuk menyampaikan kepada orang-orang mengenai suatu produk. Sedangkan menurut Lee dan Johnson (2007:3) periklanan adalah komunikasi komersil dan non-personal tentang sebuah organisasi dan produk atau jasa yang ditransmisikan ke suatu khalayak target melalui media bersifat massal seperti televisi, radio, koran, majalah, direct mail, reklame luar ruang atau kendaraan umum.

Dalam kamus istilah desain grafis dan periklanan (2008:4) iklan atau advertisement adalah suatu pemberitahuan yang memperlihatkan sesuatu untuk dijual bisa berupa produk atau jasa; suatu video singkat yang ditayangkan televisi atau pengumuman radio yang mencoba untuk membujuk orang-orang agar menggunakan produk atau jasa yang ditayangkan atau diumumkan; sebuah pengumuman atau pemberitahuan tentang sesuatu kepada publik atau orang banyak yang muncul di media dan telah dibayar.

\section{Fungsi Iklan}

Fungsi iklan menurut Triadi dan Bharata (2010:14) adalah :

a. Memberikan informasi atas produk

b. Membujuk dan mempengaruhi konsumen untuk mengkonsumsi produk

c. Menciptakan kesan atau image yang baik tentang produk

d. Memuaskan keinginan (ingin mengetahui kandungan gizi, vitamin atau harga suatu produk)

e. Merupakan alat komunilkasi

f. Menjaring khalayak

Iklan sendiri mempunyai banyak fungsi, menurut Lee dan Johnson (2007:10-11) diantaranya :

a. Pemberi informasi

Mengkomunikasikan informasiinformasi produk, ciri-ciri, dan lokasi penjualannya. Iklan memberitahu konsumen tentang produk baru.

b. Persuasif

Iklan mencoba membujuk para konsumen untuk membeli merkmerk tertentu atau mengubah sikap para konsumen terhadap produk atau perusahaan tertentu.

c. Pengingat

Iklan terus menerus mengingatkan para konsumen tentang sebuah produk, sehingga konsumen tetap membeli produk yang diiklankan tanpa mempedulikan merk pesaingnya.

Menurut Triadi dan Bharata (2010:4-5) menjelaskan dalam dunia periklanan terdapat dua media periklanan yang digunakan, yaitu :

a. Above the line seperti iklan TV, radio, search engine dan lai-lain

b. Below the line seperti poster, spanduk, brosur dan lain-lain. 


\section{Iklan Yang Efektif}

Menurut Shimp (2003:415) iklan yang efektif (baik) mencakup beberapa pertimbangan antara lain :

a. Iklan harus memperpanjang suara strategi pemasaran

b. Iklan harus menyertakan sudut pandang konsumen

c. Iklan harus persuasif

d. Iklan harus menemukan cara yang unik untuk menerobos kerumunan iklan pada pengiklan secara continue berkompetisi dengan para pesaingnya dalam menarik perhatian konsumen.

\section{Korupsi}

Korupsi atau rasuah (bahasa Latin: corruptio dari kata kerja corrumpere yang bermakna busuk, rusak, menggoyahkan, memutarbalik, menyogok) adalah tindakan pejabat publik, baik politisi maupun pegawai negeri, serta pihak lain yang terlibat dalam tindakan itu yang secara tidak wajar dan tidak legal menyalahgunakan kepercayaan publik yang dikuasakan kepada mereka untuk mendapatkan keuntungan sepihak.

Dari sudut pandang hukum, tindak pidana korupsi secara garis besar memenuhi unsur-unsur sebagai berikut:

a. Perbuatan melawan hukum,

b. Penyalahgunaan kewenangan, kesempatan, atau sarana,

c. Memperkaya diri sendiri, orang lain, atau' korporasi, dan

d. Merugikan keuangan negara atau perekonomian negara.

Jenis tindak pidana korupsi di antaranya, namun bukan semuanya, adalah
a. Memberi atau menerima hadiah atau janji (penyuapan),
b. Penggelapan dalam jabatan,
c. Pemerasan dalam jabatan,

d. Ikut serta dalam pengadaan (bagi pegawai negeri/penyelenggara negara), dan

e. Menerima gratifikasi (bagi pegawai negeri/penyelenggara negara).

Dalam arti yang luas, korupsi atau korupsi politis adalah penyalahgunaan jabatan resmi untuk keuntungan pribadi. Semua bentuk pemerintah|pemerintahan rentan korupsi dalam prakteknya. Beratnya korupsi berbeda-beda, dari yang paling ringan dalam bentuk penggunaan pengaruh dan dukungan untuk memberi dan menerima pertolongan, sampai dengan korupsi berat yang diresmikan, dan sebagainya. Titik ujung korupsi adalah kleptokrasi, yang arti harafiahnya pemerintahan oleh para pencuri, dimana pura-pura bertindak jujur pun tidak ada sama sekali. (http://id.wikipedia.org/ wiki/Korupsi).

\section{Penyebab Korupsi}

Sebagaimana dikatakan Yamamah bahwa ketika perilaku materialistik dan konsumtif masyarakat serta sistem politik yang masih "mendewakan" materi maka dapat "memaksa" terjadinya permainan uang dan korupsi (Ansari Yamamah, 2009:54). Dengan kondisi itu hampir dapat dipastikan seluruh pejabat kemudian terpaksa korupsi kalau sudah menjabat".

Menurut Nur Syam (2000:67) memberikan pandangan bahwa penyebab korupsi adalah karena tergoda materi Arifin mengemukakan faktor-faktor penyebab terjadinya korupsi antara lain karena aspek perilaku individu, aspek organisasi dan aspek masyarakat tempat individu dan organisasi berada. Sebab manusia terdorong untuk melakukan korupsi antara lain karena sifat tamak manusia, moral yang kurang kuat 
menghadapi godaan, gaya hidup konsumtif, tidak mau bekerja keras.

Menurut Erry Riyana Hardjapamekas (2008:78) menyebutkan tingginya kasus korupsi di negeri ini disebabkan karena keteladanan dan kepemimpinan elite bangsa, rendahnya gaji Pegawai Negeri Sipil, lemahnya komitmen dan konsistensi penegakan hukum dan peraturan perundangan, rendahnya integritas dan profesionalisme, mekanisme pengawasan internal di semua lembaga perbankan, keuangan, dan birokrasi belum mapan, kondisi lingkungan kerja, tugas jabatan, dan lingkungan masyarakat, dan lemahnya keimanan, kejujuran, rasa malu, moral dan etika. Secara umum faktor penyebab korupsi dapat terjadi karena faktor politik, hukum dan ekonomi. (ICW: 2000) yang mengidentifikasikan empat faktor penyebab korupsi yaitu: - Politik merupakan salah satu penyebab terjadinya korupsi memberikan gambaran bahwa politik uang (money politik) sebagai use of money and material benefits in the pursuit of political influence. Menurut Susanto korupsi pada level pemerintahan adalah dari sisi penerimaan, pemerasan uang suap, pemberian perlindungan, pencurian barang publik untuk kepentingan pribadi, tergolong korupsi yang disebabkan oleh konstelasi politik

Sementara menurut De Asis, korupsi politik misalnya politik uang pada pemilu penyelesaian konflik parlemen melalui cara ilegal dan teknik lobi yang menyimpang (De Asis (2000:31).

a. Hukum dilihat dari lemahnya perundang-undangan dan lemahnya penegakan hukum oleh aparat Negara. Dikemukakan pula oleh Basyaib, dkk yang menyatakan bahwa lemahnya sistem peraturan memberikan peluang untuk melakukan tindak pidana korupsi. Rahman Saleh merinci ada empat faktor dominan penyebab merajalelanya korupsi di Indonesia, yakni faktor penegakan hukum, mental aparatur, kesadaran masyarakat yang masih rendah, dan rendahnya „political will $\square$.

b. Ekonomi, korupsi dilakukan oleh orang kaya dan berpendidikan tinggi. Kurangnya gaji dan pendapatan pegawai negeri memang merupakan faktor yang paling menonjol dalam arti menyebabkan merata dan meluasnya korupsi di Indonesia dikemukakan pula oleh dengan situasi demikian para pegawai terpaksa mencari penghasilan tambahan dan bahwa banyak diantara mereka mendapatkannya dengan meminta uang ekstra. Pada dasarnya korupsi bukan disebabkan oleh kemiskinan, tapi kemiskinan disebabkan oleh korupsi.

c. Birokrasi, kurang adanya teladan dari pimpinan, tidak adanya kultur organisasi yang benar, sistem akuntabilitas di instansi pemerintah kurang memadai, manajemen cenderung menutupi korupsi di dalam organisasinya.

\section{Dampak Korupsi}

Secara teoritik, korupsi di sebuah Negara seperti Indonesia apabila tidak segera diatasi akan dapat menimbulkan dampak yang merusak terhadap produktivitas industri, pertumbuhan serta kemajuan ekonomi dan sosial secara keseluruhan (Mahmood, 2005:62).

Menurut Goolsarran (2006:61), korupsi menyebabkan sejumlah dampak terhadap perekonomian dimana: (1) barang dan jasa menjadi lebih banyak memakan biaya sehingga merugikan kualitas dan standar kehidupan masyarakat; (2) perdagangan yang terdistorsi karena preferensi lebih 
diberikan kepada barang dan jasa yang dapat menawarkan tingkat penyuapan yang tinggi; (3) akumulasi tingkat hutang publik jangka panjang yang tinggi akibat dari kecenderungan pemerintahan yang korup untuk memakai dana pinjaman luar negeri dalam membiayai proyek-proyek yang padat modal; serta (4) terjadinya misalokasi sumberdaya yang langka dan tidak diperhatikannya sejumlah daerah yang membutuhkan prioritas pembangunan akibat pejabat yang korup lebih mementingkan daerah lain yang dapat menghasilkan lebih banyak keuntungan pribadi buat dirinya.

Dalam konteks Indonesia, menurut Widjajabrata dan Zacchea (2004:37) korupsi setidaknya telah menyebabkan 2 (dua) dampak utama terhadap perekonomian, yakni: (1) korupsi merupakan penghambat utama dari pertumbuhan ekonomi akibat dampak negatif yang ditimbulkannya terhadap investasi dan pertumbuhan sektor swasta; serta (2) menjauhnya dan bahkan larinya investor luar negeri dari Indonesia akibat korupsi yang semakin menjadi di Ipdonesia selain dikarenakan kolapsnya sejumlah infrastruktur dasar yang penting dalam investasi. Lebih jauh menurut Basyaib, Holloway dan Makarim (2003) korupsi tidak hanya merugikan keuangan negara, tetapi juga merupakan pelanggaran hak-hak sosial dan ekonomi masyarakat, menggerogoti kesejahteraan dan demokrasi, merusak aturan hukum, dan memundurkan pembangunan.

\section{Kritik Sosial}

Kata kritik berasal dari bahasa Yunani "kritike" artinya "pemisahan" dan "krinoo" artinya "memutuskan, mempertimbangkan, dan menyatakan pendapat" (Ensiklopedia Indonesia, 1983:1891). Sementara kata "sosial" berasal dari bahasa Latin "socius" berarti kawan, teman dan masyarakat" (Soekanto,
1986:3). Dari dua pengertian tersebut, kritik sosial didefinisikan sebagai salah satu bentuk pernyataan pendapat dalam masyarakat dengan fungsi mengontrol jalannya suatu sistemi dan siruktur sosiai (Zaini, 1994:3).

Penulis sendiri mendefinisikan kritik sosial sebagai sebuah bentuk komunikasi dalam masyarakat untuk menyatakan pendapat dan untuk mengkritisi fenomena-fenomena sosial. Ini terutama karena wacana kritik sosial berkaitan erat dengan perlawanan atas kekuasaan yang hegemonik dan cenderung mempertahankan status quo.

Kritik sosial dipahami sebagai bentuk komunikasi yang dikemukakan baik dalam bentuk tulisan maupun lisan, berkenaan dengan masalah interpersonal, serta bertujuan mengontrol jalannya sistem sosial.

\section{METODE PENELITIAN}

Metodologi pada penelitian ini yaitu metode studi kasus. Menurut Rachmat Kriyantono (2006:66) metode studi kasus yaitu metode riset yang menggunakan berbagai sumber data yang bisa digunakan untuk meneliti, menguraikan dan menjelaskan secara komprehensif berbagai aspek individu, kelompok, suatu program, organisasi atau peristiwa secara sistematis.

Studi kasus adalah metode riset yang menggunakan berbagai sumber data (sebanyak mungkin data) yang bisa digunakan untuk meneliti, menguraikan, dan menjelaskan secara komprehensif berbagai aspek individu, kelompok, suatu program, organisasi atau peristiwa secara sistematis. Penelaahaan berbagai sumber data ini membutuhkan berbagai macam instrumen pengumpulan data. Karena itu, periset dapat menggunakan wawancara mendalam, observasi partisipan, dokumentasi-dokumentasi, kuesioner 
(hasil survei), rekaman, bukti-bukti fisik lainnya. (Kriyantono, 2006: 65).

Sementara itu, Yin (2006:18) memberi batasan mengenai studi kasus sebagai riset yang menyelidiki fenomena di dalam konteks kehidupan nyata, bilamana batas-batas antara fenomena dan konteks tak tampak dengan jelas, dan di mana multisumber dimanfaatkan.

Penggunaan metode studi kasus pada pembahasan jurnal ini adalah studi kasus dengan fokus pada bagaimana peran media iklan sebagai media pendidikan anti korupsi. Penggunaan studi kasus sebagai metode penelitian dikarenakan penelitian ini bertujuan memberikan uraian secara lengkap dan mendalam mengenai peran media iklan sebagai media pendidikan anti korupsi.

Studi kasus adalah metode riset yang menggunakan berbagai sumber data (sebanyak mungkin data) yang bisa digunakan untuk meneliti, menguraikan, dan menjelaskan secara komprehensif berbagai aspek individu, kelompok, suatu program, organisasi atau peristiwa secara sistematis. Penelaahaan berbagai sumber data ini membutuhkan berbagai macam instrumen pengumpulan data. Karena itu, periset dapat menggunakan wawancara mendalam, observasi partisipan, dokumentasi-dokumentasi, kuesioner (hasil survei), rekaman, bukti-bukti fisik lainnya. (Kriyantono, 2006: 65).

Data yang diperoleh akan dianalisis secara kualitatif yaitu anaiisis yang dilakukan dengan memaharni dan merangkai data yang telah dikumpulkan dan disusun secara sistematis, kemudian ditarik kesimpulan.

Menurut Pawito (2008:102) mengemukakan bahwa dalam penelitian kualitatif, kesimpulan yang dihasilkan pada umumnya tidak dimaksudkan sebagai generalisasi, tetapi sebagai gambaran interpretatif tentang realitas atau gejala yang diteliti secara holistik dalam setting tertentu. Di sini, dikandung arti bahwa temuan apapun yang dihasilkan pada dasarnya bersifat terbatas pada kasus yang diamati. Oleh karena itu, prinsip berfikir induktif lebih menonjol dalam penarikan kesimpulan dalam penelitian komunikasi kualitatif.

Dengan demikian, metode kualitatif menurut Bogdan \& Taylor dalam Ruslan (2010:215) diharapkan mampu meghasilkan suatu uraian mendalama tentang ucapan, tulisan, dan tingkah laku yang dapat diamati dari suatu individu, kelompok, masyarakat, organisasi tertentu dalam suatu konteks setting tertentu yang dikaji dari sudut pandang yang utuh, komprehensif dan holistic.

Berdasarkan tataran atau cara menganalisis data, penelitian ini termasuk dalam jenis penelitian deskriptif. Sejalan dengan hal tersebut, Moleong (2002: 11) mengemukakan bahwa salah satu karakteristik dalam penelitian kualitatif adalah deskriptif. Dalam hal ini data yang dikumpulkan berupa kata-kata, gambar dan bukan angka-angka. Hal ini disebabkan oleh adanya penerapan metode kualitatif. Selain itu, semua yang dikumpulkan berkemungkinan menjadi kunci terhadap apa yang sudah diteliti. Dengan demikian, laporan penelitian akan berisi kutipan-kutipan data untuk memberi gambaran penyajian laporan tersebut.

Data yang diambil peneliti dalam penulisan ini di dapat melalui studi kepustakaan atau surnber tertulis (library research). Secara umum definisi studi kepustakaan adalah usaha yang dilakukan oleh peneliti untuk menghimpun informasi yang relevan dengan topik atau masalah yang akan atau sedang diteliti. Informasi itu dapat diperoleh dari bukubuku ilmiah, laporan penelitian, karangan-karangan ilmiah, tesis dan disertasi, peraturan-peraturan, ketetapan- 
ketetapan, buku tahuna, ensiklopedia dan sumber-sumber tertulis baik tercetak maupun elektronik lainnya.

Menurut Ruslan (2010:31) "Riset kepustakaan adalah riset yang dilakukan untuk mencari data atau informasi riset melalui menbaca jurnal ilmiah, bukubuku, referensi dan bahan-bahan publikasi yang tersedia diperpustakaan".

Data-data yang digunakan dalam pembahasan jurnal ini yaitu data secara studi pustaka diperoleh dari beberapa sumber buku dan sumber lainnya seperti internet yang relevan dengan pembahasan dan data terkait iklan Djarum 76 versi "Kontes Jin".

\section{PEMBAHASAN}

Masalah korupsi yang terjadi di Indonesia sudah sangat mengkhawatirkan dan berdampak buruk luar biasa pada hampir seluruh sendi kehidupan. Korupsi telah menghancurkan sistem perekonomian, sistem demokrasi, sistem politik, sistem hukum, sistem pemerintahan, dan tatanan sosial kemasyarakatan di negeri ini. Dilain pihak upaya pemberantasan korupsi yang telah dilakukan selama ini belum menunjukkan hasil yang optimal. Korupsi dalam berbagai tingkatan tetap saja banyak terjadi seolah-olah telah menjadi bagian dari kehidupan kita yang bahkan sudah dianggap sebagai hal yang biasa. Jika kondisi ini tetap kita biarkan berlangsung maka cepat atau lambat korupsi akan menghancurkan negeri ini.

Korupsi harus dipandang sebagai kejahatan luar biasa (extra ordinary crime) yang oleh karena itu memerlukan upaya luar biasa pula untuk memberantasnya. Upaya pemberantasan korupsi - yang terdiri dari dua bagian besar, yaitu (1) penindakan, dan (2) pencegahan -tidak akan pernah berhasil optimal jika hanya dilakukan oleh pemerintah saja tanpa melibatkan peran serta masyarakatdan industri media. Oleh karena itu media iklan dapat dijadikan sebagai salah satu bagian penting yang dapat berperan sebagai media kritik sosial mengenai masalah korupsi di 'Indonesia. Iklan dalam kajian media massa merupakan media yang unik karena memuat segala macam seni di dalamnya, seni yang beragam dalam pengelolaan sebuah produksi karya.

Media elektronik kini menjadi ladang bagi produsen untuk memperkenalkan produknya melalui sebuah iklan. Iklan ditampilkan dengan berbagai kreativitas agar iklan tampak menarik. Namun, dengan kreativitas kreator, iklan, di sisi lain, mewacanakan yang bukan hanya memperkenalkan produk. Wacana tersebut dapat ditelusuri melalui analisis terhadap iklan tersebut. Seperti Indonesia memiliki banyak perkebunan tembakau dan cengkeh, bukan tidak - mungkin banyak produsen rokok berkembang di Indonesia. Dengan banyaknya produsen rokok, usaha menarik minat konsumen untuk mengonsumsi produknya menjadi semakin kreatif.

Iklan rokok sebagian' besar tidak menampilkan rokok sebagai produk, tetapi melalui sebuah kisah dalam iklan. Salah satu iklan rokok yang tidak menampilkan rokok sebagai produk yang unggul, adalah iklan rokok Djarum 76 . Iklan selalu menampilkan dua hal, yaitu aspek verbal dan non-verbal. Aspek verbal meliputi tulisan dan lisan atau dialog. Aspek non-verbal meliputi warna, kostum, latar, tokoh, dan sebagainya yang bukan aspek kebahasaan. Keduanya tidak dapat dipisahkan karena akan saling membangun keutuhan sebuah iklan.

Iklan Djarum 76 seperti yang kita ketahui seringkali menampilkan tematema sosial yang kemudian dapat kita pahami sebagai bentuk kritik sosial. Dengan memunculkan sosok jin dalam 
setiap iklannya, Djarum 76 berusaha menceritakan produknya sebagai produsen yang konsen terhadap masalahmasalah sosial. Citra yang muncul dari iklan tersebut adalah Djarum 76 peduli akan masalah-masalah sosial yang ada, yang kemudian dimunculkan dalam bentuk parodi namun sarat akan makna dan kritik sosial.

Dalam iklan audio visual Djarum 76 versi "Kontes Jin", iklan ini berkonsep kontes, maka muncullah wacana persaingan antar-peserta kontes. Ketiga jin menunjukkan keahlian berupa menghilangkan benda atau objek. Dalam kontes tersebut terdapat 3 peserta antara lain jin dari Arab, jin dari Jepang dan jin dari Indonesia. Jin Indonesia ditampilkan serba Jawa, yaitu blangkon, beskap, dan sewek (jarik).

Kontes pun di mulai, sebagai peserta kontes pertama jin dari Arab berhasil menghilangkan objek Piramida yang merupakan kebanggaan dan ciri khas negara Mesir dengan kata "Piramida...Lenyap!", kontestan kedua jin dari Jepang' juga berhasil menghilangkan gunung Fujiyama atau yang dikenal dengan gunung keabadian yang merupakan gunung kebanggaan masyarakat Jepang dengan ujaran "Fujiyama...hilang!". Sedangkan, Jin Indonesia mendatangkan tumpukan berkas yang meninggi jauh dari bibir kardus. Kemudian, Jin tersebut mengatakan "llang!". Alhasil, apa yang dilakukan Jin Indonesia tersebut ditertawakan oleh kedua jin lainnya. Jin Indonesia, lalu, cukup geram dengan berkata, "Kasus korupsi..hilang". Sambutan dari para penontonmu meledak. Kedua jin lain akhirnya bersujud dan masing-masing berkata "Edan" dan "Ajaib" di samping kardus bertuliskan "Kasus Korupsi". Jin Indonesia mampu menghilangkan kasus korupsi yang bersifat laten.

Pada akhirnya, Jin Indonesia keluar sebagai pemenang karena kehebatannya yang tidak dapat dilakukan oleh siapapun. Sebab sampai saat ini, kasus korupsi terutama di Indonesia belum dapat dituntaskan. Fenomena korupsi ibarat gunung es, yang tidak tampak jauh lebih banyak daripada yang tampak. Penonton yang bersorak tampil dengan pakaian seragam dan batik. Salah satu penonton mirip dengan Gayus Tambunan, orang yang tersangkut kasus korupsi. Kembali iklan ini menampilkan hal yang berbau korupsi. Namun, sosok mirip Gayus ini ikut bersorak sorai merayakan

keberhasilan Jin Indonesia menghilangkan kasus korupsi. Berikut scene iklan Djarum 76 versi "Kontes Jin":

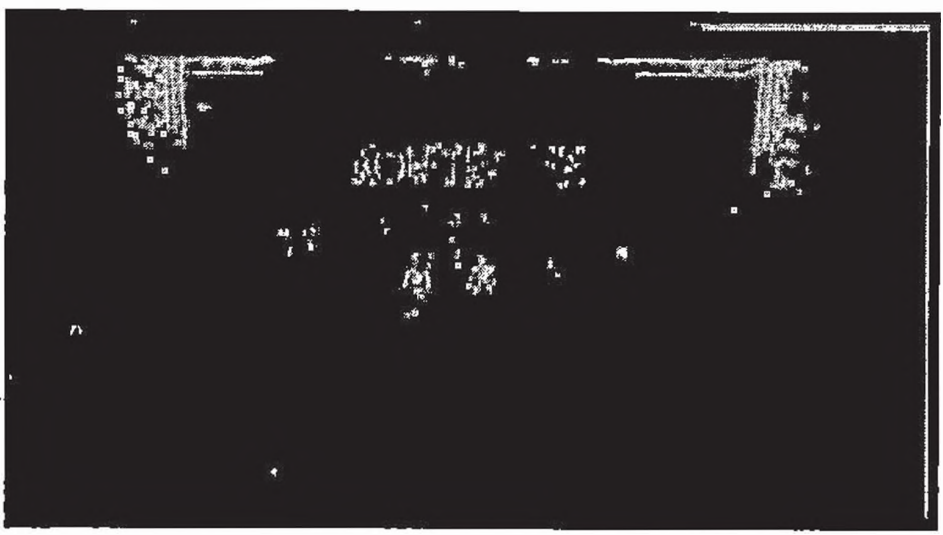

Gambar. Scene 1

Panggung dan peserta Kontes Jin 
Jurnal komunikasi, Volume 9, Nomor 2, April 2015

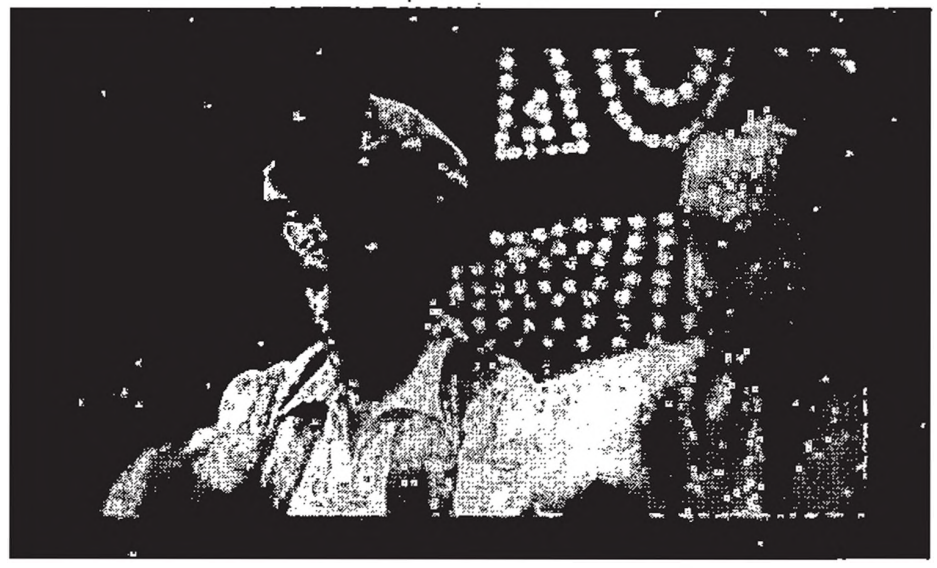

Gambar scene 2.

Peserta kontes Jin Arab dan Jepang
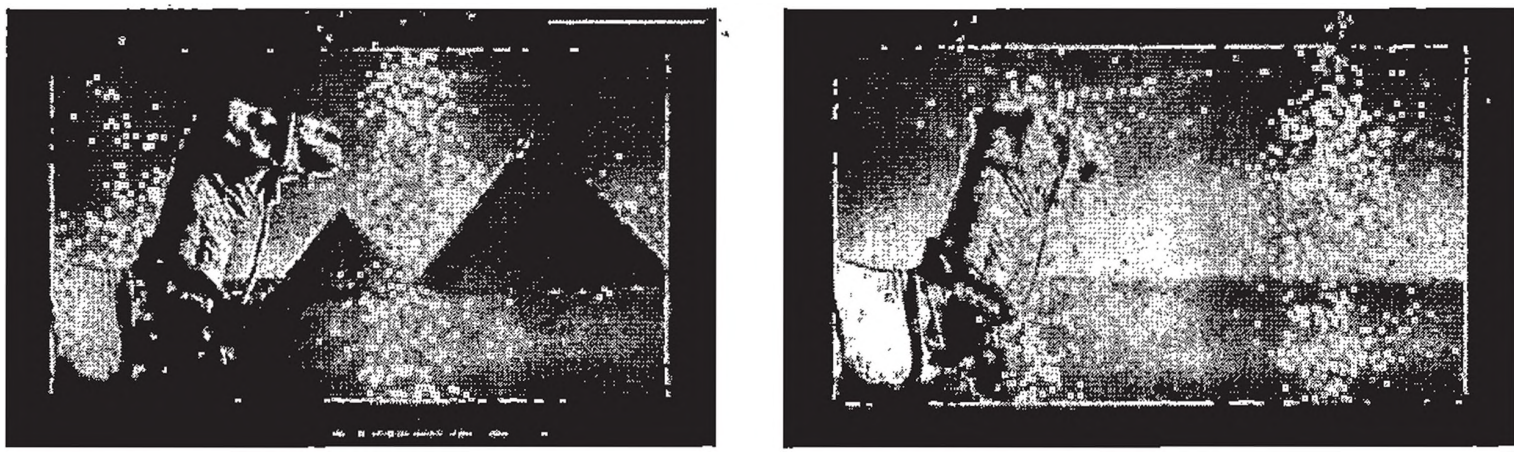

Gambar scene 3 .

Jin Arab berhasil menghilangkan Piramida bangunan prasejarah dan ciri khas negara Mesir

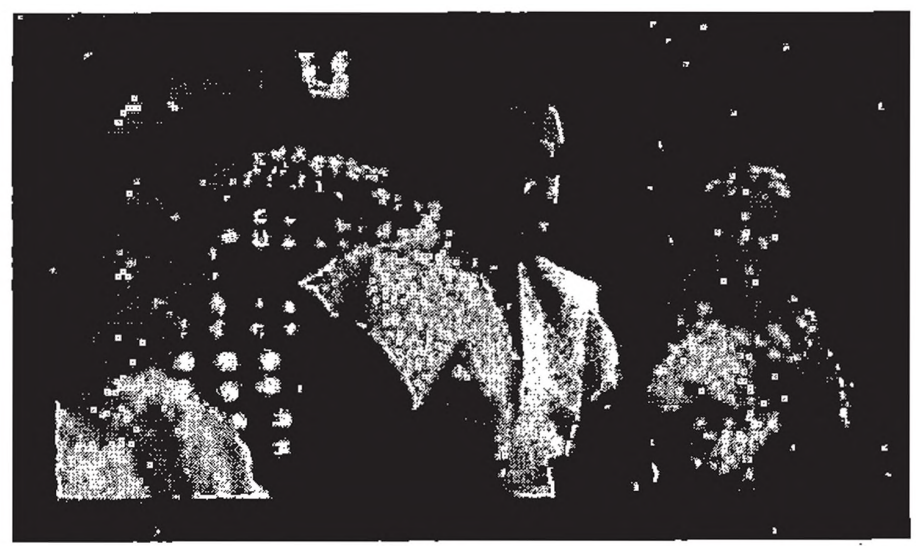

Gambar. Scene 4 Aksi dari jin Jepang 

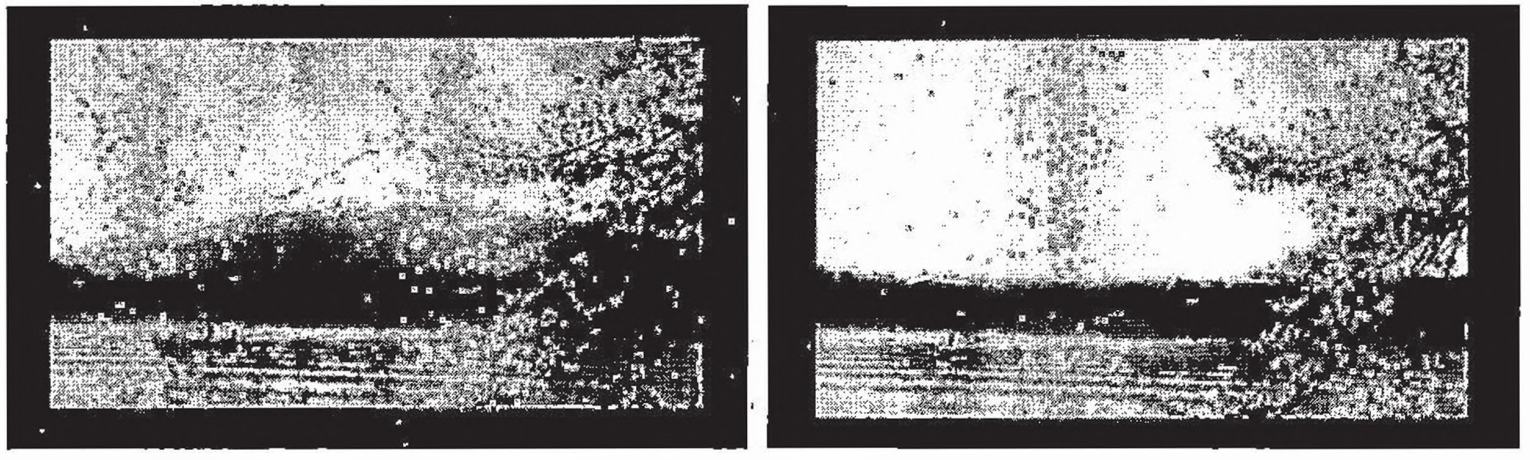

Gambar. Scene 5

Jin Jepang berhasil menghilangkan gunung Fujiyama yang merupakan gunung kebanggaan negara Jepang

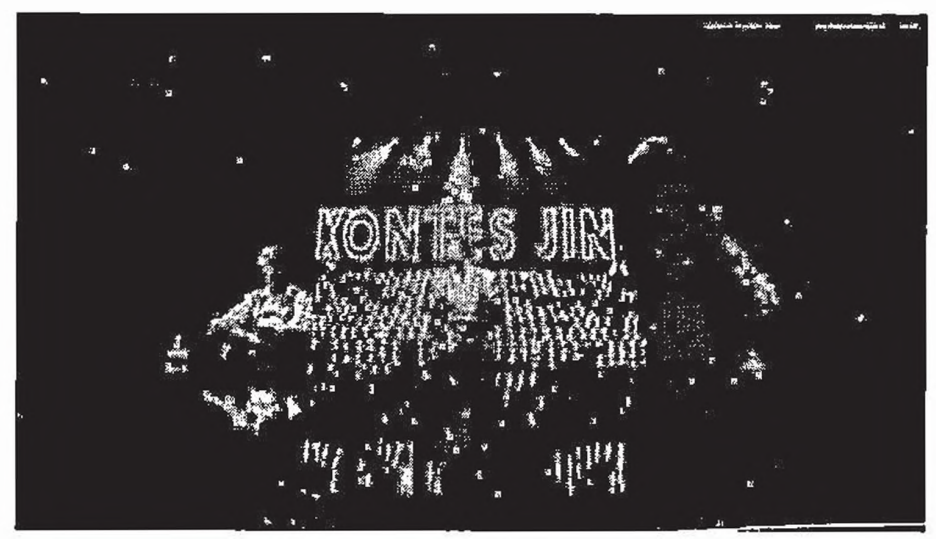

Gambar. Scene 6

Peserta kontes Jin ke tiga, Jin Indonesia beraksi dengan membawa setumpuk kertas yang dimasukkan dalam kardus

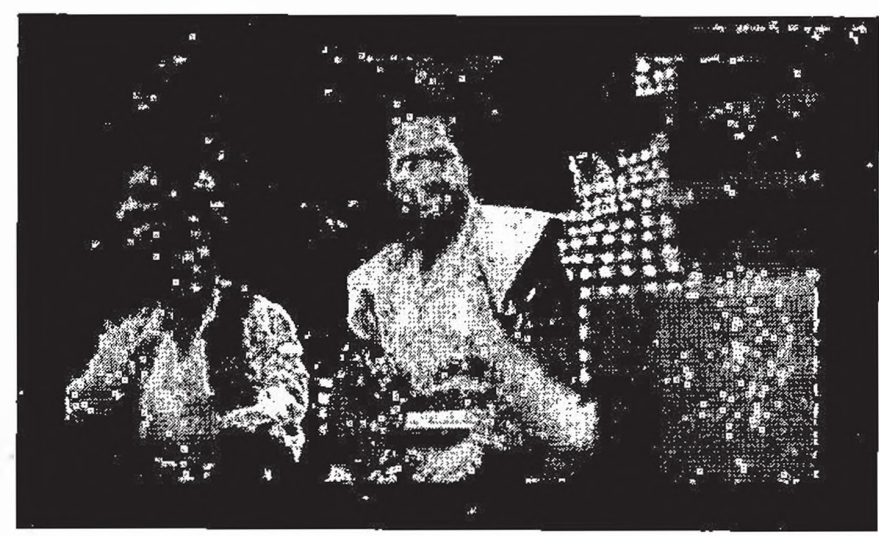

Gambar. Scene 7

Jin Arab dan Jin Jepang terlihat binggung atas aksi yang dilakukan oleh Jin Indonesia 
Jurnal komunikasi, Volume 9, Nomor 2, April 2015

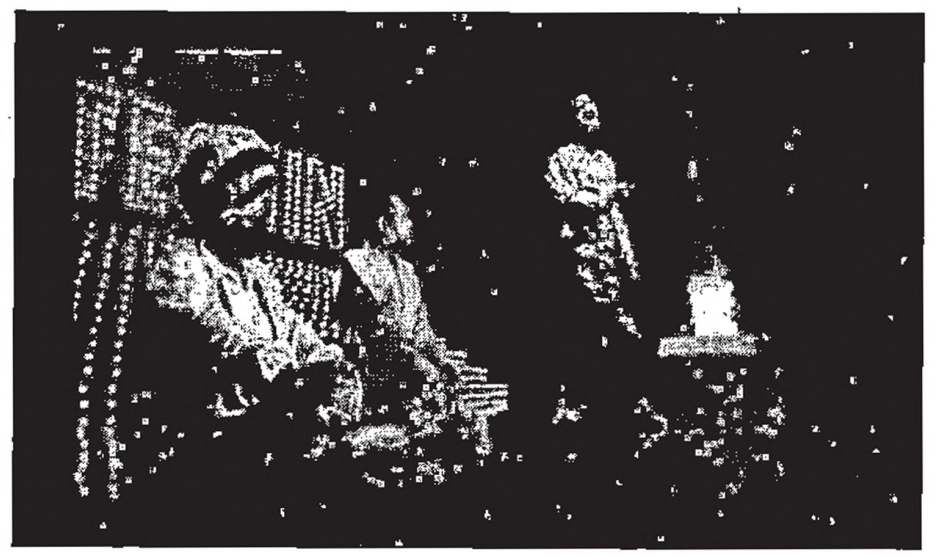

Gambar. Scene 8

Jin Indonesia beraksi dengan menghilangkan setumpuk kertas yäng ada dihadapannya

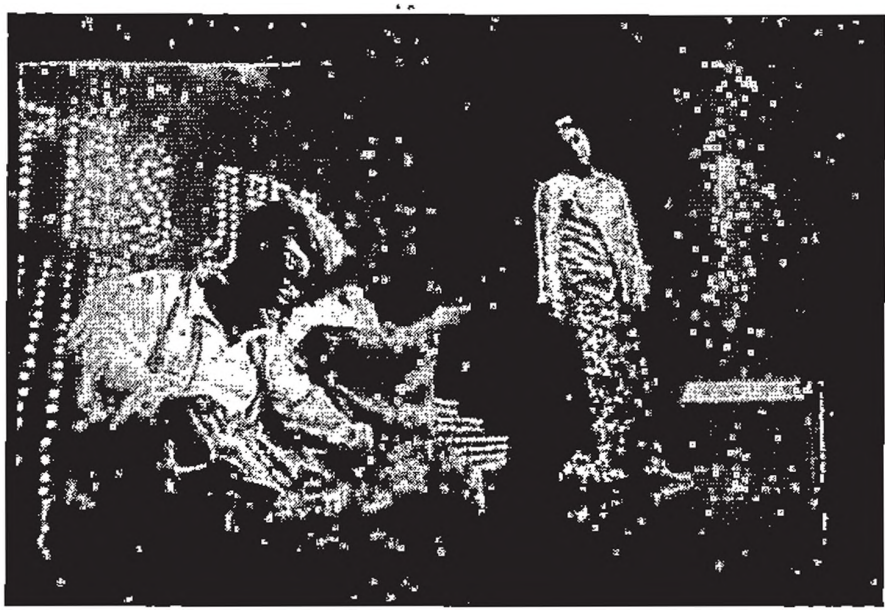

Gambar. Scene 9

Jin Arab dan Jin Jepang tertawa melihat aksi dari Jin Indonesia

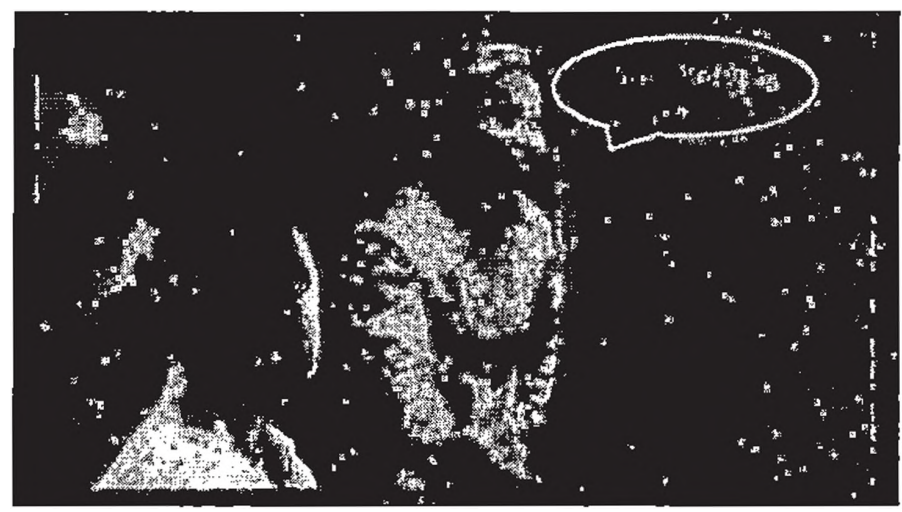

Gambar. Scene 10

Jin Indonesia berkata "Kasus Korupsi Hilang" 


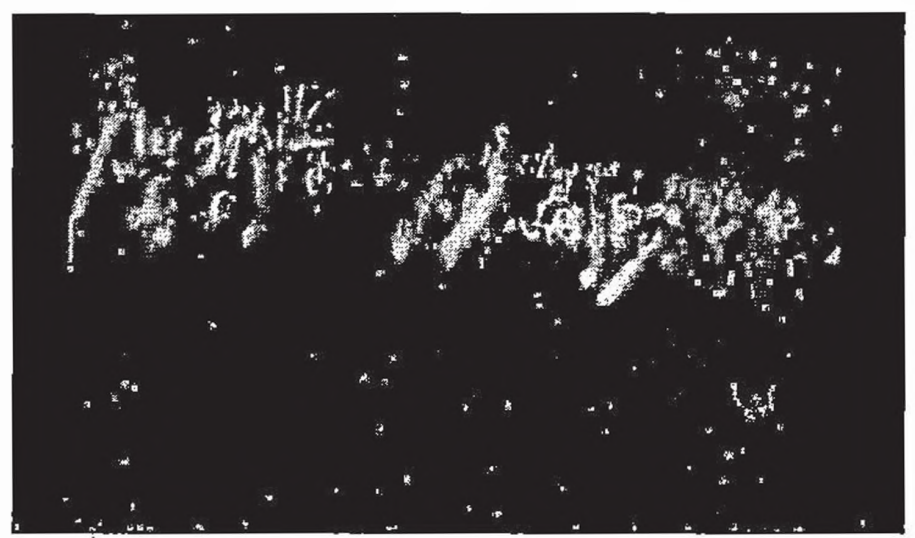

Gambar. Scene 11

Penonton bersorak gembira melihat aksi Jin Indonesia yang berhasil menghilangkan kasus korupsi di Indonesia

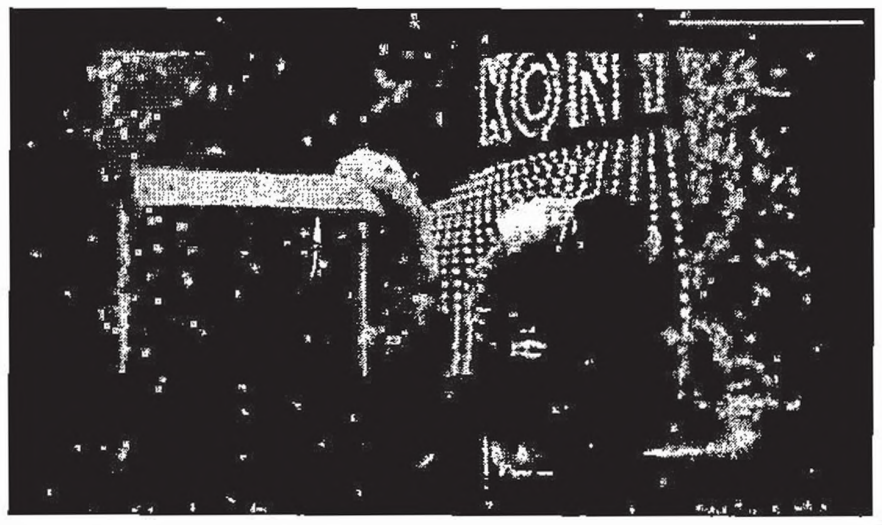

Gambar. Scene 12

Kedua kontestan Jin Arab dan Jin Jepang memberi hormat kepada Jin Indonesia

(tampak di samping kardus bertuliskan "kasus korupsi")

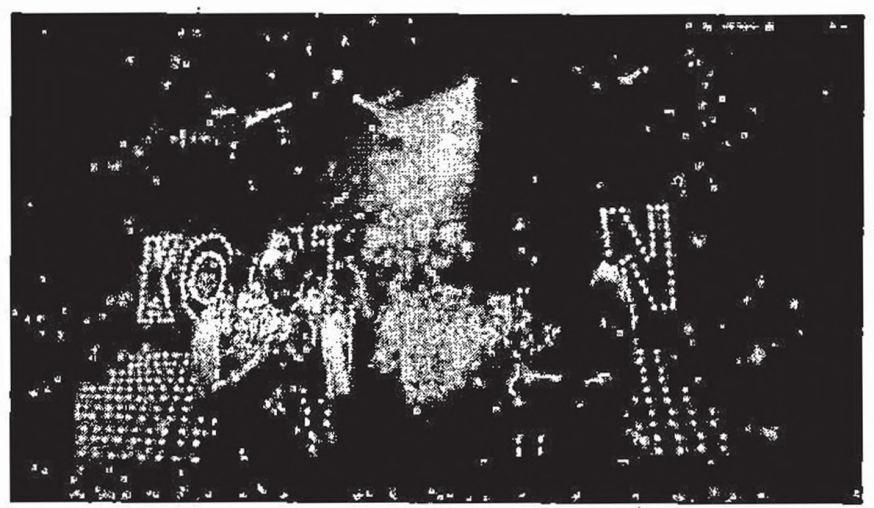

Gambar. Scene 13

Jin Indonesia keluar sebagai pemenang “kontes Jin" 


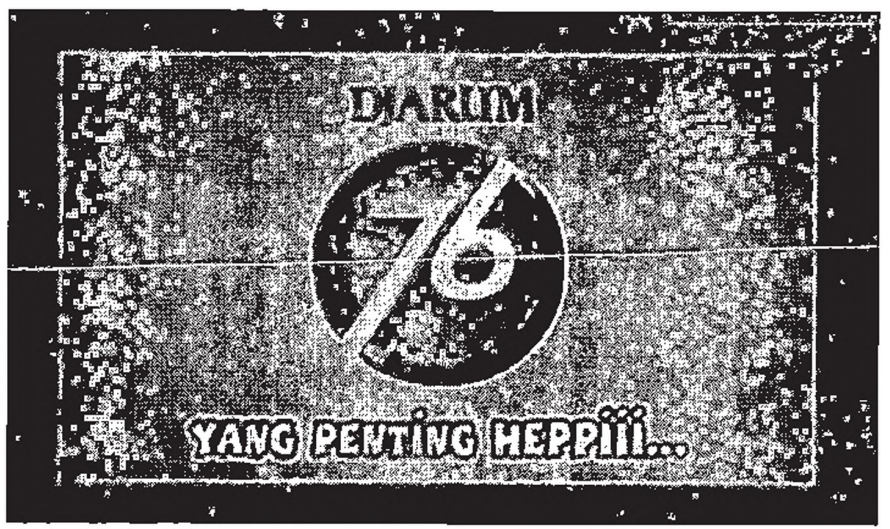

\section{Gambar. Scene 14 \\ Tampilan penutup iklan Djarum 76 versi "Kontes Jin" yang terkenal dengan slogan "Yang Penting Heppiii...."}

\section{KESIMPULAN}

Dari uraian di atas, secara keseluruhan iklan ini merupakan bentuk kritik sosial yang membicarakan kasus korupsi. Penghilangan kasus korupsi disambut hangat oleh semua orang yang direpresentasikan oleh penonton. Namun, ada suatu sindiran yang ditemui, yaitu apakah menunggu munculnya jin untuk menuntaskan kasus korupsi. Sindiran ini tertuju pada pihak-pihak terkait yang pada kenyataannya belum mampu mengusut semua kasus korupsi. Satu kasus membutuhkan waktu yang lama untuk dituntaskan, sedangkan seorang jin menuntaskan semua dalam satu kedipan mata.

: Ada satu hal lagi yang perlu diperhatikan dalam iklan ini, yaitu pembuka dan penutup. Sudah dijelaskan sebelumnya, pembuka dan penutup memiliki kemiripan. Jika dianalogikan dengan wayang, tampilnya langit, matahari, dan awan serupa dengan tampilnya Gunungan atau Kayon. Warna jingga dominan dalam iklan ini, yaitu latar pada pembukaan, beskap pada Jin Indonesia, dinding bingkai panggung termasuk tirainya, dan latar bagian penutup. Selain itu, ada kemiripan antara bagian pembuka dan penutup, terutama pada kompisisinya. Kemiripan tersebut meliputi warna latar, awan, dan matahari. Latar pada pembuka dan penutup didominasi jingga dengan gradasi kuning emas. Pada bagian pembuka, awan tampak asli, tetapi pada bagian penutup awan tampak seperti motif batik. Matahari muncul dengan sinarnya hampir tepat di tengah pada pembuka. Pada menutup muncul lingkaran 76 di tengah dan diapit oleh tulisan "Djarum" pada bagian atas, dan "Yang penting hepii" pada bagian bawah. Jingga, dalam aura, memiliki sifat kepedulian, intuitif, bijaksana, dan mudah bergaul. Dengan demikian, jingga dihadirkan untuk penguatan isi iklan.

Dengan demikian, dapat dipahami bahwa rangkaian peristiwa dalam iklan tersebut tidaklah nyata. $\mathrm{Hal}$ ini mempertegas sindiran yang diutarakan dalam isinya. Namun, dengan slogan Djarum 76, apapun yang terjadi "Yang Penting Hepii...". Slogan ini semacam hiburan agar penonton tidak sedih oleh kasus korupsi yang tak berkesudahan. 


\section{DAFTAR PUSTAKA}

Basyaib, Hamid, Richard Holloway dan Nono Anwar Makarim (Editor). 2002. Mencuri Uang Rakyat: 16 Kajian Korupsi di Indonesia Buku 14. Jakarta: Yayasan Aksara.

College, Maria Regina. 2008. Kamus Istilah Desain Grafis dan Periklanan. Jakarta: PT Elex Media Komputindo.

De Asis, Maria Gonzales. 2000. CoalitionBuilding to Fight Corruption, Paper Prepared for the Anti-Corruption Summit, World Bank Institute.

Ensiklopedia, Indonesia. 1983. Ichtiar Baru-Van Hoeve Jilid 4. Jakarta.

Goolsarran, Swatantra Anand. 2006. "Corruption: Its Nature, Causes and Effects Suggestions on the Way Forward". The Journal of Government Financial Management. Volume 55. No. 1

ICW. 2000. Peran Parlemen dalam Membasmi Korupsi Jakarta: ICW.

Kriyantono, Rachmat. 2006. Teknik Riset Komunikasi. Jakarta: PT Rajagrafindo Persada

Monle Lee dan Carla Johnson. 2007. Prinsip-Prinsip Pokok Periklanan Dalam Perspektif Global. Jakarta: Kencana Prenada Media Group.

Mahmood, Mabroor. 2005. "Corruption in Civil Administration: Causes and Cures", Humanomics. Volume 21. No. 3 / 4
Pawito. 2008. Penelitian Komunikasi Kualitatif. Yogyakarta: LKIS Pelangi Aksara.

Ricky W. Griffin dan Ronald J. Elbert. 2007. Bisnis. Jakarta: Erlangga.

Ruslan, Rosady. 2010. Metodologi Penelitian Public Relations dan Komunikasi cetakan ke-5. Jakarta: Rajawali Pers.

Shimp, Terence. 2003. Periklanan Promosi, Apek Tambahan Komunikasi Terpadu. Jakarta: Erlangga

Soekanto, Soerjono. 1986. Sosiologi Suatu Pengantar. Jakarta: Rajawali Press.

Triadi, Dendy dan Addy Sukma Bharata. 2010. Ayo Bikin Iklan: Memahami Teori \& Praktek Iklan Media Lini Bawah. Jakarta: PT Elex Media Komputindo.

Widjajabrata, Safaat and Nicholas M Z acchea. 2004. "International Corruption: The Republic of Indonesia is Strengthening the Ability of Its Auditors to Battle Corruption". The Journal of Government Financial Management. Volume 53. No. 3

Zaini, Akhmad. 1994. Kritik Sosial, Negara dan Demokrasi, Republika. 


\section{Sumber lain :}

Ansari Yamamah. 2009. diunduh dari Perilaku-Konsumtif-Penyebab-

Korupsi http://dellimanusantara.com/index.ph p (di akses pada 15 Oktober 2014).

Erry R. Hardjapamekas. 2008. Melawan Korupsi Tugas Kita Semua http://www.fokal.info/fokal/arsip/ars ip-hukum/365.html (di akses pada 15 Oktober 2014).

http://id.wikipedia.org/wiki/Korupsi (di akses pada 17 Oktober 2014)

Nur Syam. 2009. Penyebab Korupsi http://nursyam.sunan-ampel.ac.id (di akses pada 15 Oktober 2014). 